\title{
First records of tardigrades (Tardigrada) from Irish and Scottish leaf litter
}

\author{
B. Blagden ${ }^{1+}$, ${ }^{*}$ E. DeMilio ${ }^{2+}$, J.G. Hansen ${ }^{3}$ \& R.M. Kristensen ${ }^{3}$
}

${ }^{1}$ Scottish Environment Protection Agency, Inverdee House, Baxter Street, Aberdeen AB11 9QA

${ }^{2}$ Department of Zoology, Ryan Institute, National University of Ireland Galway, University Road, Galway, Republic of Ireland

${ }^{3}$ Natural History Museum of Denmark, University of Copenhagen, Universitetsparken 15, 2100 Copenhagen, Denmark

*E-mail: erica.demilio@gmail.com

+ Authors contributed equally to this work.

\begin{abstract}
The findings of an investigation of the tardigrade fauna associated with beech (Fagus sylvatica) leaf litter in the Republic of Ireland and Scotland are reported. The present study is the first to specifically target this microhabitat in either country. Tardigrades were extracted from 16 samples of leaf litter obtained from seven locations (one in Ireland and six in Scotland). Twenty five tardigrade taxa were encountered including seven that represent new records for the Republic of Ireland (Pseudechiniscus sp. nov., Diphascon pingue group sp., Hypsibius cf. convergens, Hypsibius cf. scabropygus, Itaquascon cf. globuliferum, Ursulinius sp. nov., and Minibiotus sp. nov.) and four for Scotland (Bertolanius weglarskae, Hypsibius cf. scabropygus, Adropion belgicae and Pilatobius ramazzottii). The collection of several taxa that either represent new records or undescribed species within a small number of samples demonstrates the importance for researchers to include leaf litter when assessing and reporting the tardigrade biodiversity of an area.
\end{abstract}

\section{INTRODUCTION}

Tardigrades (phylum Tardigrada) are microscopic, invertebrates that require a film of water around their bodies to maintain normal activity. However, they are well known for their ability to survive periods of desiccation and other unfavourable environmental conditions. As a consequence, tardigrades are capable of inhabiting diverse marine, freshwater and moist terrestrial habitats worldwide (Kinchin, 1994; Sømme, 1996; McInnes, 1994; Guidetti et al., 2011).

Despite their seemingly ubiquitous nature (e.g. Nelson, 2002; Nelson et al., 2019), knowledge of the limnoterrestrial tardigrade fauna of the Republic of Ireland (hereafter referred to as "Ireland"), Scotland and the remainder of the U.K. is predominantly based on studies of mosses and lichens as microhabitats (e.g. Murray, 1905a, 1905b, 1906a, 1906b, 1907, 1911a, 1911b; Le Gros, 1955, 1957; Morgan, 1976; Morgan \& King, 1976; Wright, 1991; DeMilio et al., 2016; Morek et al., 2016; Stec et al., 2017). Other studies carried out in England included rain gutter sediment (Bertolani \& Kinchin, 1993) or a small number of leaf litter samples among more numerous mosses or lichens (Greaves, 1991; Greaves \& Marley, 1994; Nattress et al., 2014). To date no studies on tardigrades associated with the leaf litter habitat have been undertaken in Ireland or Scotland. The present study therefore represents the first attempt to collect data on the tardigrade species inhabiting leaf litter in either country.

Although it has long been known that tardigrades occur in leaf litter (Mihelčič, 1949), globally there have been relatively few studies reporting on the abundance and species richness of tardigrades in this habitat (e.g. Iharos, 1967, 1973; Hallas \& Yeates, 1972; Greaves, 1991; Greaves \& Marley, 1994; Beasley \& Cleveland, 1996; Bertolani \& Rebecchi, 1996; Guidetti et al., 1999; Guidetti \& Bertolani, 2001; Ito \& Abe, 2001; Hohberg, 2006; Hinton \& Meyer, 2007; Nelson \& Bartels, 2007; Guil, 2008; Guil et al., 2008, 2009; Hinton et al., 2010, 2014; Guil \& Sánchez-Moreno, 2013; Nelson \& Bartels, 2013; Nattress et al., 2014; Meyer, 2015; Roszkowska et al., 2019). Of these, five are known to have included beech (Fagus sylvatica) leaf litter. Beech litter was found by Guil \& Sánchez-Moreno (2013) to harbour the most diverse composition of tardigrade taxa among the compared leaf litter types. Some tardigrade species previously recorded from beech litter were reported from across a broad geographical area (Guidetti et al., 1999). As these included several species not previously found within Ireland and the U.K., it was hypothesised that an examination of Irish and Scottish beech litter could reveal the presence of species new to the Irish and U.K. fauna and contribute to a better understanding of the distribution of tardigrades and their ecological associations in both countries.

\section{MATERIALS AND METHODS}

Sixteen samples of beech leaf litter were opportunistically collected; ten from throughout a single woodland site in Ireland, Barna Woods, Co. Galway (B1-B10); and six separate sites in Scotland with four samples from the north east (Aberdeenshire and Morayshire), one sample from the Lake of Menteith, Stirlingshire, and one sample from the western shore of Loch Ness, Highland. As far as possible the inclusion of soil was prevented by taking samples from a minimum 
of $1.5 \mathrm{~cm}$ above the underlying soil. The collection of mixed leaf litter was also avoided.

Samples were either processed immediately or retained to dry in paper envelopes. In each case a small sample (weighing approximately 15-25 g) of leaf litter was soaked for up to $24 \mathrm{~h}$ before being agitated by hand and squeezed into shallow trays. Tardigrades, eggs, and exuvia were removed and mounted on glass slides in polyvinyl alcohol (Irish specimens) or Hoyer's medium (Scottish specimens) and secured with a cover slip. Slides were dried at approximately $22^{\circ} \mathrm{C}$ (Irish material) for two days or $60^{\circ} \mathrm{C}$ (Scottish material) for five days before being sealed with clear nail varnish. Juvenile animals were observed but not included in the species total counts. Specimens were examined on an Olympus BX51 with up to x100 oil immersion lens and $\mathrm{x} 2$ magnification changer with differential interference contrast (DIC), and phase contrast (PhC) optics. Photographs and measurements of specimens were obtained using Cell D software (dp2020). Measurements were taken following Pilato (1981) except where otherwise noted and are given in micrometres $(\mu \mathrm{m})$. The $p t$ index is the ratio of the length of a given structure to the length of the buccal tube, expressed as a percentage (Pilato, 1981). The ptd index (Pilato \& Binda, 1997/98) is used to obtain a similar ratio for taxa that have an evident drop-shaped thickening between the rigid buccal tube and flexible pharyngeal tube, as the buccalpharyngeal apparatus configuration requires a different caudal reference mark for the buccal tube measurement. Individual structures were measured only if their orientation was suitable.

Identifications of specimens were made via comparisons with the original species descriptions, additional relevant literature, or by comparisons with type material whenever possible. Natural History Museum of Denmark (NHMD) catalogue numbers of the examined material are given below. The taxonomic account and systematics follow the most recently available checklist of tardigrade species (Guidetti \& Bertolani, 2005; Degma \& Guidetti, 2007; Degma et al., 2019). Usage of open nomenclature follows the recommendations of Sigovini et al. (2016).

\section{Sample locations}

Ireland: Barna Woods, County Galway, Ireland. Date of collection: 20/06/2016

Irish grid reference: 'M24442378'

B1. 53 ${ }^{\circ} 15^{\prime} 31^{\prime \prime} \mathrm{N}, 9^{\circ} 07^{\prime} 54^{\prime \prime} \mathrm{W}$, Alt. $26.2 \mathrm{~m}$

B2. 53 $15^{\prime} 35^{\prime \prime} \mathrm{N}, 9^{\circ} 07^{\prime} 43^{\prime \prime} \mathrm{W}$, Alt. $28.0 \mathrm{~m}$

B3. $53^{\circ} 15^{\prime} 36^{\prime \prime} \mathrm{N}, 9^{\circ} 07^{\prime} 60^{\prime \prime} \mathrm{W}$, Alt. $30.1 \mathrm{~m}$

B4. $53^{\circ} 15^{\prime} 34^{\prime \prime} \mathrm{N}, 9^{\circ} 08^{\prime} 01^{\prime \prime} \mathrm{W}$, Alt. $33.1 \mathrm{~m}$

B5. $53^{\circ} 15^{\prime} 37^{\prime \prime} \mathrm{N}, 9^{\circ} 08^{\prime} 03^{\prime \prime} \mathrm{W}$, Alt. $32.9 \mathrm{~m}$

B6. $53^{\circ} 15^{\prime} 41^{\prime \prime} \mathrm{N}, 9^{\circ} 07^{\prime} 53^{\prime \prime} \mathrm{W}$, Alt. $26.0 \mathrm{~m}$

B7. $53^{\circ} 15^{\prime} 41^{\prime \prime} \mathrm{N}, 9^{\circ} 07^{\prime} 33^{\prime \prime} \mathrm{W}$, Alt. $26.2 \mathrm{~m}$

B8. $53^{\circ} 15^{\prime} 51^{\prime \prime} \mathrm{N}, 9^{\circ} 07^{\prime} 02^{\prime \prime} \mathrm{W}$, Alt. $24.5 \mathrm{~m}$

B9. $53^{\circ} 13^{\prime} 50^{\prime \prime} \mathrm{N}, 9^{\circ} 07^{\prime} 09^{\prime \prime} \mathrm{W}$, Alt. $27.5 \mathrm{~m}$

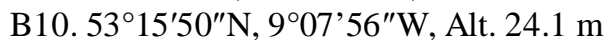

Scotland: Dates of collection: 07/11/2015 and 30/04/2016

Battle Hill, Huntly, Aberdeenshire. 57² $6^{\prime} 56^{\prime \prime} \mathrm{N}$, $2^{\circ} 45^{\prime} 40^{\prime \prime} \mathrm{W}$, Alt. $175 \mathrm{~m}$

Fochabers, Winding Walks Wood, Morayshire. $57^{\circ} 36^{\prime} 26^{\prime \prime} \mathrm{N}, 3^{\circ} 04^{\prime} 16^{\prime \prime} \mathrm{W}$, Alt. $154 \mathrm{~m}$

Invermoriston, Loch Ness, Highland. $57^{\circ} 12^{\prime} 40^{\prime \prime} \mathrm{N}$, $4^{\circ} 36^{\prime} 48^{\prime \prime} \mathrm{W}$, Alt. $49 \mathrm{~m}$

Lake of Menteith, Stirlingshire. $56^{\circ} 10^{\prime} 22^{\prime \prime} \mathrm{N}$, $4^{\circ} 16^{\prime} 25^{\prime \prime} \mathrm{W}$, Alt. $27 \mathrm{~m}$

Leith Hall, Kennethmont, Aberdeenshire. 57² $21^{\prime} 14^{\prime \prime} \mathrm{N}$, $2^{\circ} 45^{\prime} 41^{\prime \prime} \mathrm{W}$, Alt. $181 \mathrm{~m}$

Slug Road, Stonehaven, Aberdeenshire. 56 $59^{\prime} 12.43^{\prime \prime} \mathrm{N}$, $2^{\circ} 15^{\prime} 40^{\prime \prime} \mathrm{W}$, Alt. $58 \mathrm{~m}$

\section{RESULTS}

All 16 samples contained tardigrades (Table 1). In total 506 (including five encysted) adult individuals, and 81 eggs were collected. The number of adult individuals per sample ranged from two to 130 . Twenty-five taxa were represented. Seven taxa have not been previously recorded from Ireland. Four taxa have not been previously recorded from Scotland.

Taxonomic Account

Class Heterotardigrada Marcus, 1927

Order Echiniscoidea Richters, 1926

Family Echiniscidae Thulin, 1928

Subfamily Echiniscinae Guil, Jørgensen \& Kristensen, 2019

Tribe Echiniscini Guil, Jørgensen \& Kristensen, 2019

Echiniscus quadrispinosus quadrispinosus (Richters, 1902)

Scotland: Leith Hall, one adult.

The collected specimen was typical of the species. This is the first known record of the species from leaf litter.

Subfamily Pseudechiniscinae Guil, Jørgensen \& Kristensen, 2019

Tribe Pseudechiniscini Guil, Jørgensen \& Kristensen, 2019

\section{Pseudechiniscus sp. nov.}

Ireland: Barna Woods: B5, 1 adult; B8, 2 adults. One male and two females specimens belonging to the genus Pseudechiniscus Thulin, 1911 were collected. Following a comparison with the descriptions all known species of the genus it was determined that the Irish specimens could not be assigned to any known taxon due to the unique morphology of the cephalic sense organs.

The recent works of Cesari et al. (2019) and Tumanov (2019) have addressed the taxonomic difficulties associated with Pseudechiniscus. Despite the advancements presented by these authors, the P. suillusfacettalis species complex remains particularly problematic in the absence of a re-description of P. suillus (Ehrenberg, 1853), the nominal species of the complex and genus type. While the morphology of the cephalic sense organs of the collected specimens clearly 


\begin{tabular}{|c|c|c|c|c|c|c|c|c|c|c|c|c|c|c|c|c|}
\hline Taxon & B1 & B2 & B3 & B4 & B5 & B6 & B7 & B8 & B9 & B10 & BH & FO & $\mathbf{I N}$ & $\mathbf{L M}$ & LH & SR \\
\hline Echiniscus quadrispinosus quadrispinosus & - & - & - & - & - & - & - & - & - & - & - & - & - & - & 1 & - \\
\hline Pseudechiniscus sp. nov.I & - & - & - & - & 1 & - & - & 2 & - & - & - & - & - & - & - & - \\
\hline Bertolanius weglarskae & - & - & - & - & - & - & - & - & - & - & 1 & 2 & 5 & 3 & - & - \\
\hline Diphascon pingue pingue & - & - & 1 & - & - & - & - & 1 & - & - & 1 & 2 & 1 & - & - & 2 \\
\hline Diphascon pingue group sp. ${ }^{\mathrm{I}}$ & - & - & - & - & - & - & - & - & 1 & - & - & - & - & - & - & - \\
\hline Hypsibius cf. convergens ${ }^{\mathbf{I}}$ & 1 & - & - & - & - & - & - & 2 & - & - & - & - & - & - & - & - \\
\hline Hypsibius cf. dujardini & 1 & 1 & 1 & - & - & 2 & - & - & 4 & 1 & 2 & - & 3 & - & - & 3 \\
\hline Hypsibius cf. scabropygus ${ }^{\mathbf{I}, \mathbf{S}}$ & 1 & - & - & - & - & - & - & - & - & - & 3 & - & - & - & - & - \\
\hline Adropion belgicae $\mathbf{s}$ & - & - & - & - & - & - & - & - & - & - & - & - & 2 & - & - & - \\
\hline Adropion prorsirostre & - & - & - & - & - & - & - & - & - & - & 4 & - & 4 & - & - & 7 \\
\hline Adropion scoticum scoticum & - & 3 & - & - & - & - & - & 1 & - & - & 32 & 19 & 6 & 1 & - & 3 \\
\hline Astatumen trinacriae & - & - & - & - & - & - & - & - & - & - & 5 & - & 3 & - & - & 1 \\
\hline Itaquascon cf. globuliferum ${ }^{\mathbf{I}}$ & - & - & - & - & - & - & - & - & 1 & - & - & - & - & - & - & - \\
\hline Mesocrista indet. & - & - & - & - & - & - & - & - & - & - & - & - & - & - & - & 1 \\
\hline Pilatobius bullatus & 2 & - & - & - & 1 & - & - & 4 & - & - & - & - & - & - & - & - \\
\hline Pilatobius ramazzottil $\mathbf{s}$ & - & - & - & - & - & - & - & - & - & - & - & - & - & - & 4 & - \\
\hline Ramazzottius indet. & - & - & - & - & - & - & - & - & - & - & 1 & - & - & - & - & - \\
\hline Isohypsibius prosostomus & - & 1 & - & - & - & - & - & 1 & - & - & - & - & - & - & - & 2 \\
\hline Dianea sattleri & 6 & - & - & 1 & 1 & 3 & - & 11 & 4 & 1 & - & - & - & - & - & - \\
\hline Ursulinius sp. nov. I & - & 1 & 2 & 1 & - & - & - & - & - & - & - & - & - & - & - & - \\
\hline Macrobiotus hufelandi group indet. & 2 & 2 & - & 1 & - & 1 & - & 21 & 2 & - & 2 & - & - & 7 & 2 & 4 \\
\hline Mesobiotus harmsworthi group sp. & - & 6 & 4 & 3 & 4 & 8 & 2 & 18 & 3 & 2 & 3 & - & 23 & - & - & - \\
\hline Minibiotus sp. nov. I & - & - & - & - & - & - & - & 2 & - & - & - & - & - & - & - & - \\
\hline Paramacrobiotus cf. richtersi & 2 & - & 3 & 20 & 29 & 9 & - & 67 & 5 & - & 8 & 24 & 7 & 18 & 3 & - \\
\hline Murrayon hibernicus & - & - & - & - & - & - & - & $\mathrm{E}$ & - & - & - & - & - & - & - & - \\
\hline
\end{tabular}

Table 1. Systematical list of tardigrades, including encysted adults, collected from each sample. Locations: B1-10, Barna Woods, County Galway, Ireland; BH, Battle Hill, Huntly, Aberdeenshire,

Scotland; FO, Fochabers, Winding Walks Wood, Morayshire, Scotland; IN, Invermorriston, Loch Ness, Highland, Scotland; LM, Lake of Menteith, Stirlingshire, Scotland; LH, Leith Hall,

Kennethmont, Aberdeenshire, Scotland; SR, Slug Road, Stonehaven, Aberdeenshire, Scotland. E, egg only; I, new record for Ireland; S, new record for Scotland. 
differs from that of $P$. suillus sensu lato, a clarified definition of that taxon is desired prior to any formal description of the collected specimens so that a complete suite of characters may be compared.

Class Eutardigrada Marcus, 1927

Order Eohypsibioidea Bertolani \& Kristensen, 1987

Family Eohypsibiidae Bertolani \& Kristensen, 1987

Bertolanius weglarskae (Dastych, 1972)

Scotland: Battle Hill, one cyst; Fochabers, two adults, three eggs; Invermoriston, one adult, four cysts, two eggs; Lake of Menteith, three adults, two eggs.

The adult (Fig. 1A,B) specimens and eggs conform to previous descriptions given by Dastych (1972) and Bertolani (1981) and to the illustrations and photomicrographs in Hansen et al. (2016), which also provides a key to the species of the genus. Morphometric values of selected characters of the Scottish specimens are given in Table 2 .

Along with adults and eggs, five Type 2 cysts (Hansen \& Katholm, 2002; Hansen et al., 2016) were collected (Fig. 1C). These cysts, a dormancy life stage produced in response to adverse environmental conditions (see Bertolani et al., 2019), varied in colour though were predominantly red or red-brown. In transmitted light, following mounting on slides in Hoyer's medium, all cysts appear brown.

$B$. weglarskae has been previously recorded from beech leaf litter in Italy by Guidetti et al. (1999) and Guidetti $\&$ Bertolani (2001). This is the first record of the species for Scotland.
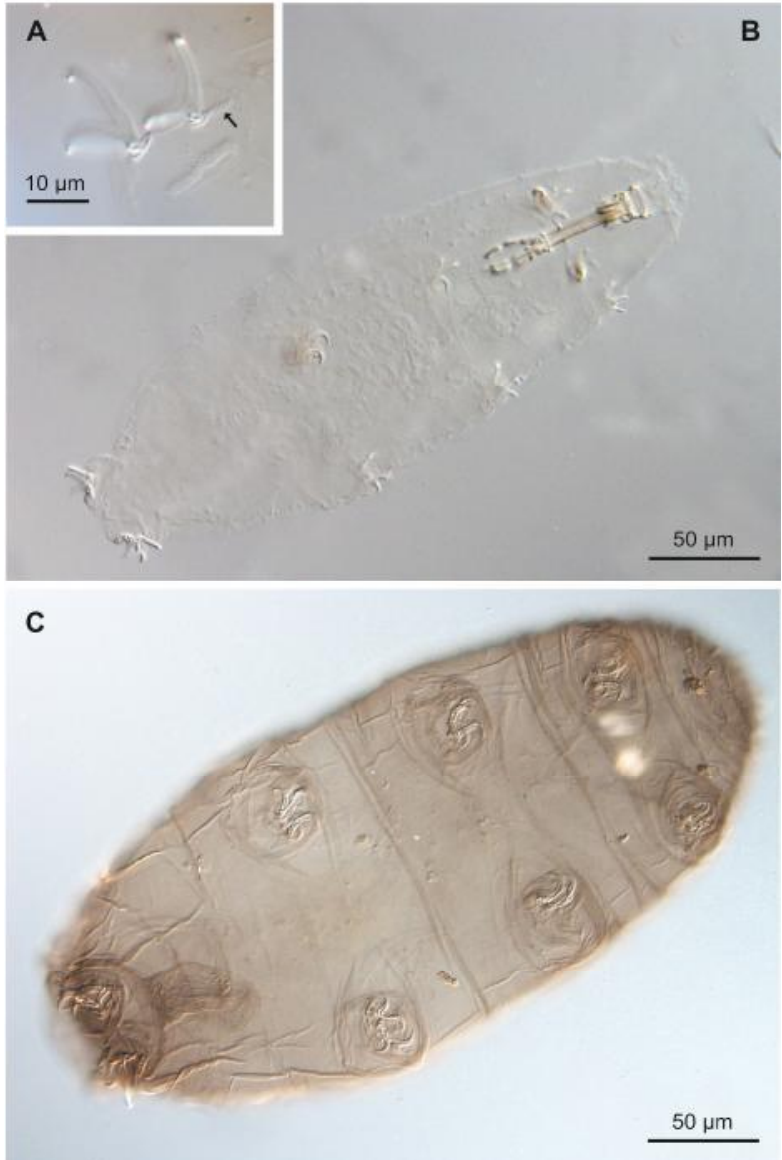

Fig. 1. Bertolanius weglarskae observed by differential interference contrast microscopy. (A) Claws on second leg pair. Black arrow indicates the cuticular bar positioned beside the internal double claw. (B) Habitus. (C) Type 2 cyst. (Photos: B. Blagden)

\begin{tabular}{llllllll}
\hline & & \multicolumn{3}{c}{$\boldsymbol{\mu m}$} & \multicolumn{3}{c}{$\boldsymbol{p t}$} \\
\cline { 5 - 8 } Character & $\mathbf{n}$ & Range & Mean & SD & Range & Mean & SD \\
\hline Body length & 6 & $269-638$ & 443 & 148 & $685-1091$ & 909 & 171 \\
Buccal tube length & 6 & $39.2-58.5$ & 47.7 & 7.8 & - & - & - \\
Stylet support insertion point & 6 & $30.7-46.1$ & 37.2 & 6.0 & $76.4-78.7$ & 78 & 0.9 \\
Buccal tube external width & 6 & $5.3-8.9$ & 6.8 & 1.4 & $13.1-15.2$ & 14.1 & 0.8 \\
Macroplacoid 1 length & 6 & $6.2-10.8$ & 8.4 & 2.0 & $15.5-19.3$ & 17.5 & 1.5 \\
Macroplacoid 2 length & 6 & $5.4-10.2$ & 8.0 & 1.9 & $13.8-19.2$ & 16.6 & 2.2 \\
Macroplacoid 3 length & 6 & $6.3-13.9$ & 10.3 & 2.6 & $16.0-25.1$ & 21.5 & 3.2 \\
Macroplacoid row length & 6 & $20.9-37.2$ & 29.3 & 6.4 & $53.2-67.1$ & 61.0 & 5.0 \\
External claw pair I primary branch length & 6 & $10.3-18.3$ & 14.7 & 3.4 & $26.3-33.4$ & 30.4 & 3.2 \\
External claw pair II primary branch length & 6 & $11.1-20.6$ & 16.5 & 3.6 & $28.3-37.5$ & 34.3 & 3.2 \\
External claw pair III primary branch length & 6 & $13.1-21.1$ & 17.3 & 3.8 & $32.1-41.3$ & 35.9 & 3.7 \\
Posterior claw pair IV primary branch length & 6 & $15.4-27.8$ & 21.4 & 5.0 & $39.2-48.1$ & 44.5 & 4.0 \\
\hline
\end{tabular}

Table 2. Selected morphometric data for Scottish Bertolanius weglarskae specimens. n, number of individuals measured; $p t, p t$ index; $\mathrm{SD}$, standard deviation. 
Order Hypsibioidea Pilato, 1969

Family Hypsibiidae Pilato, 1969

Subfamily Diphasconinae Dastych, 1992

Diphascon pingue pingue (Marcus, 1936)

Ireland: Barna Woods: B3, one adult; B8, one adult. Scotland: Battle Hill, one adult; Fochabers, two adults; Invermoriston, one adult; Slug Road, two adults. Pilato \& Binda (1997/1998; 1999) provided a detailed discussion of the Diphascon pingue group. This group of morphologically similar species comprises Diphascon Plate, 1888 that possess a smooth cuticle, three rod-shaped macroplacoids, microplacoid, and septulum and lack lunules or indentations of the claw bases and cuticular thickening on the legs (Fontoura \& Pilato, 2007). All Irish and Scottish specimens (except one treated separately below) conform to the redescription of $D$. pingue by Pilato \& Binda (1997/98). Identification of the specimens was confirmed through measurements of taxonomic characters according to Pilato \& Binda (1997/1998; 1999). Qualitative and quantitative characters including the calculated ptd indices for measured structures fell within the species ranges given for $D$. pingue by Pilato \& Binda (1997/1998; 1999). The specimens were also identifiable as $D$. pingue via the dichotomous key for the group by Fontoura \& Pilato (2007). The collection of these specimens of $D$. pingue pingue from Barna Woods confirms the presence of the species in Ireland (see DeMilio et al. 2016).

"Diphascon pingue" has been recorded among several leaf litter types in many locations. These previous records include beech litter from the U.S.A. (Guidetti et al., 1999) and Italy (Guidetti \& Bertolani, 2001) and various other litter types from the U.S.A. (Hinton \& Meyer, 2007; Nelson \& Bartels, 2007; Hinton et al., 2010; Hinton et al., 2014), Italy (Lisi, 2015; Roszkowska et al., 2019), Germany (Hohberg, 2006), New Guinea (Iharos, 1967, 1973) and Spain (Guil \& Sánchez-Moreno, 2013). However, it is possible that some older records actually represent other similar species in the pingue group.

\section{Diphascon pingue group sp.}

Ireland: Barna Woods: B9, one adult.

One specimen from Ireland belonging to the Diphason pingue group was determined to represent a separate taxon from the $D$. pingue pingue specimens detailed above. According to the key to the pingue group by Fontoura \& Pilato (2007), this Irish pingue group specimen does not correspond well to a known species nor to species of the group described since the publication of that key (Kaczmarek et al., 2017a). Since some species of the pingue group are separated solely by quantitative differences and the collection of this single individual does not provide enough material for a complete set of morphometric data, the species identification is unresolved. However, the specimen clearly differs from those identified above as $D$. pingue by: the longer macroplacoids, the third of which is more than double the length of the equally long first and second, and the small appearance of the claws with short primary branches (claw pair I external primary branch $=4.7 \mu \mathrm{m}$, ptd $=34.4$; internal primary branch, $3.8 \mu \mathrm{m}$, ptd $=27.8$ ). Additional examples are required to identify this taxon more precisely, but it is counted as a new record for Ireland because only $D$. pingue pingue has been recorded from Ireland thus far, and the specimen clearly does not belong to that species.

\section{Subfamily Hypsibiinae Pilato, 1969}

Hypsibius cf. convergens (Urbanowicz, 1925) Ireland: Barna Woods: B1, one adult; B8, two adults. The three Irish specimens all possess a smooth, unpigmented cuticle and a buccal pharyngeal apparatus containing apophyses, two granular macroplacoids (macroplacoid 1 is longer than microplacoid 2), without microplacoid or septulum. Macroplacoid 1 has the form of an elongated granule with a subtle central constriction. Macroplacoid 2 lacks a constriction. For each of the mounted specimens, most claws were poorly oriented for obtaining a full set of morphometrics and observing structural details (no cuticular bars were observed).

The Irish specimens belong to the $H$. convergens group of species. The difficulties associated with identifications of $H$. convergens and close species have long been known (e.g. Bertolani 1982, Ramazzotti \& Maucci, 1983), yet a complete modern re-description of the nominal species of the group is still lacking. When compared with the limited data given in the original description of $H$. convergens, the Irish specimens have a shorter body length $(168,173$ and $190 \mu \mathrm{m})$ compared with the type $(300 \mu \mathrm{m})$. Urbanowicz (1925) gave only one value, $10 \mu \mathrm{m}$, as the longest length measured for an external claw on an unspecified pair of legs. After calculating $p t$ indices (Pilato, 1981) for the given claw measurement of the type of $H$. convergens, the $p t$ value of 38.5 for the external claws (unknown pair) is slightly greater than that obtained for the Irish specimens' external claws where the mean $p t$ value is 33.5 (those suitable for measurement on all leg pairs, $n=4)$.

The Irish specimens were also compared with the actual type material and re-descriptions (Kaczmarek and Michalczyk, 2009) of the similar species Hypsibius microps Thulin, 1928 and H. pallidus Thulin, 1911 (NHMD catalogue numbers: TAR-000022, TAR-000023, TAR-000024, TAR-000025). These species also have smooth, unpigmented cuticles, two granular macroplacoids and lack the microplacoid and septulum. The Irish specimens clearly do not correspond to $H$. microps, most evidently because of the shorter, more granular microplacoid 1 of $H$. microps, along with differences in the $p t$ values of measured structures. The mean $p t$ values of some structures of the Irish specimens fall within the ranges for the type material of $H$. pallidus (body length, stylet support insertion point, microplacoid 2, and external buccal tube width). However, the Irish specimens do not have "pallidus type" claw morphology and according to the re-descriptions by Kaczmarek \& Michalczyk (2009) 
neither $H$. pallidus nor $H$. microps has a constricted macroplacoid 1 as is evident in the Irish specimens. The description of another convergens group species, H. pedrottii Bertolani, Manicardi \& Gibertoni, 1987, appears somewhat similar to the Irish specimens, particularly in terms of body length and placoid morphology, but $H$. pedrottii is distinguished from other convergens group species and the Irish specimens by its notably small claws.

\begin{abstract}
"Hypsibius convergens" has been previously recorded from Italian beech litter (Guidetti et al., 1999; Guidetti $\&$ Bertolani, 2001) and German leaf litter of several tree species (Hohberg, 2006). As a complete re-description of $H$. convergens from the type locality is necessary to understand the range of variability of the species and because the limited morphometric data that are given in the species description does not match exactly to that of the Irish specimens, open nomenclature is used for the identification of these individuals. This is the first record of the taxon for Ireland.
\end{abstract}

Hypsibius cf. dujardini (Doyère, 1840)

Ireland: Barna Woods: B1, one adult; B2, one adult; B3, one adult; B6, two adults; B9, four adults; B10, one adult.

Scotland: Battle Hill, two adults; Invermoriston, three adults; Slug Road, one adult.

$H$. dujardini belongs to a species complex, the dujardini group, that has long been regarded as cosmopolitan. Species of this complex exhibit a smooth, colourless cuticle and a pharynx containing two rod-shaped macroplacoids and septula. Hypsibius dujardini has been re-described using integrative methodology by Gąsiorek et al. (2018). In terms of qualitative characteristics, the Irish and Scottish specimens are in agreement with $H$. dujardini sensu stricto as determined by Gąsiorek et al. (2018). These traits include: a stout body form with smooth cuticle, eyes, a rounded pharynx containing prominent apophyses, two oval macroplacoids (the first has a central constriction under $\mathrm{PhC}$ and is longer than the second) and an obvious septulum. Additionally, cuticular bars are absent from leg pairs I-III. A short bar is present between the claws of leg pair IV that is close to, but not in full contact with the base of the posterior claw. The bases of the internal and anterior claws are broad. A lunule is observable on the anterior claw of some specimens but this is not definitively clear on all individuals.

DeMilio et al. (in press) collected $H$. dujardini from Clare Island, Co. Mayo and considered the species to be present in Ireland on the basis of morphological evidence. However, the subsequently published re-description of the species by Gąsiorek et al. (2018) includes a range of morphometric data for a neotype population, with which those authors suggest, all other records should be compared together with supporting molecular data whenever possible. Due to the suggestion by Gąsiorek et al. (2018) that cryptic species more morphologically similar to the type might be present in the dujardini complex, open nomenclature is used for the Irish and Scottish specimens pending the collection of more individuals for further morphometric and molecular studies in order to resolve the status of the species in these two countries.

The prolific records for "Hypsibius dujardini" suggest that the species group is common in a variety of leaf litters, including beech (Guil \& Sánchez-Moreno, 2013), but the status of such records should be re-evaluated following the re-description by Gąsiorek et al. (2018).

Hypsibius cf. scabropygus Cuénot, 1929

Ireland: Barna Woods: B1, one adult. Scotland: Battle Hill, three adults.

No morphological differences between the Irish (Fig. 2A) and Scottish examples were observed. All specimens match the original species description though this can be considered outdated in terms of modern standards. Cuénot (1929) did not specify the presence or absence of cuticular bars for the species, as this character was not commonly included in descriptions of the time. The present specimens all exhibit a short cuticular bar adjacent to the posterior claw of leg pair IV (Fig. 2B). The cuticular bars of the Irish and Scottish specimens appear identical to those seen on figures of specimens identified as $H$. cf. scabropygus by Zawierucha et al. (2014) from Latvia and Estonia and similar to those described by Ciobanu et al. (2014) on the same taxon reported from Romania. The former authors considered the possibilities that Cuénot and later authors (e.g. Ramazzotti \& Maucci, 1983) could have missed the bars due to their small size or that specimens with bars represent a new species.

Guidetti \& Bertolani (2001) recorded H. cf. scabropygus from leaf litter with a variation of the egg morphology. A close species, $H$. stiliferus Abe, 2004 described from eastern Russia, exhibits cuticular bars in a similar position to the Irish, Scottish, Baltic, and Romanian specimens. These observed variations, overlap in traits with similar species, and far-ranging geographical distribution records (McInnes, 1994; McInnes et al., 2017) indicate the need for a modern re-description of the H. scabropygus in order to clarify the situation. This is the first record of the taxon for both Ireland and Scotland.

Subfamily Itaquasconinae Bartoš in Rudescu, 1964

Adropion belgicae (Richters, 1911)

Scotland: Invermoriston, two adults.

Both Scottish specimens conform to the brief description of the species by Richters (1911) based on material from Advent Bay and Hope Island, Spitsbergen, Svalbard. However, the original species description is insufficient by modern standards. Bernard (1977), recognised variation in later reports of the species by various authors from different localities and re-described the species. However, this was based on material from Michigan, U.S.A., not the original type location. Bernard (1977) suggested the possibility of the existence of a complex of similar species. This is particularly evident in the variation in the reports of the 

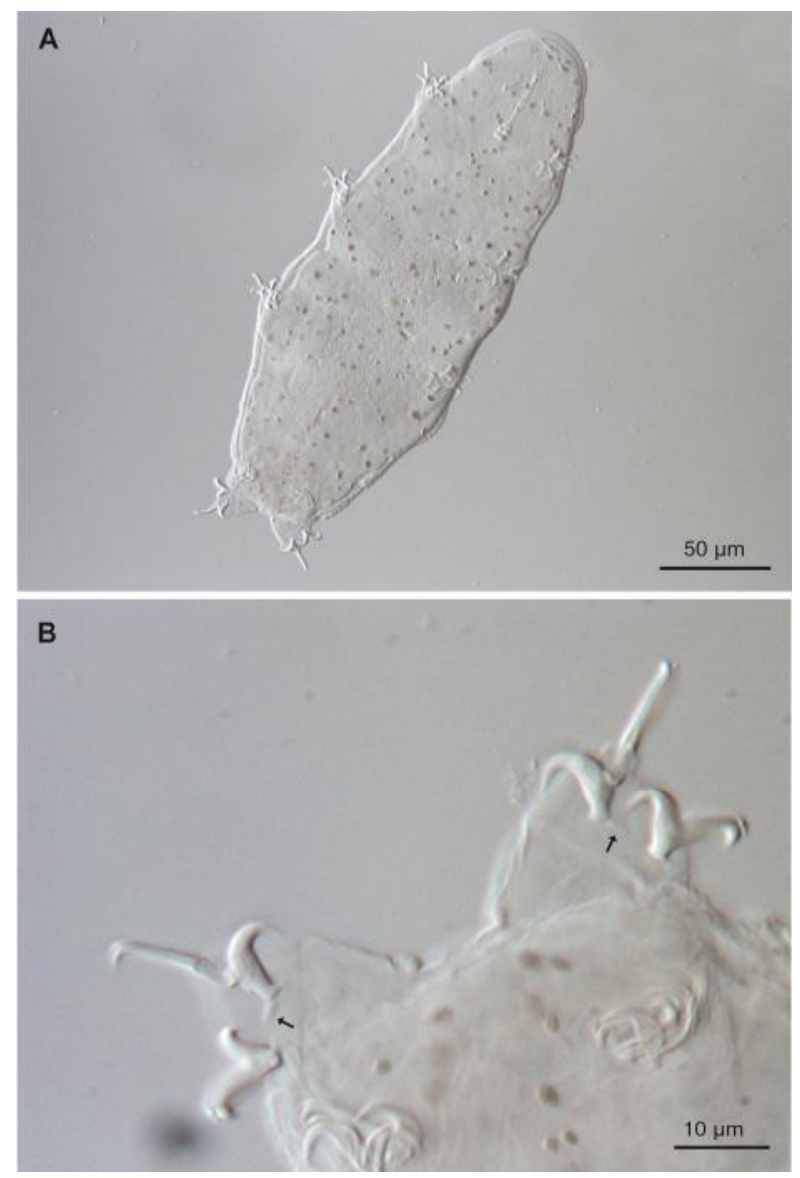

Fig. 2. Hypsibius cf. scabropygus observed by differential interference contrast microscopy. (A) Habitus. (B) Claws on fourth leg pair. Black arrows indicate the cuticular bar positioned between internal and external claw on each leg. (Photos: B. Blagden)

claw morphology. Richters (1911) described the claws as particularly unique in structure and appearing as the "oberhauseri" type, but did not state the presence or absence of associated cuticular bars. Pilato \& Binda (1977) reported the presence of two cuticular bars on the claws of leg pairs I-III and a single bar on leg pair IV in their observations of specimens of A. belgicae from an unspecified location. Bernard's (1977) re-description also suggests the presence of cuticular bars associated with the claws of all leg pairs, although these differ in number and placement compared with those observed by Pilato \& Binda. Dastych (1988) described Polish examples of $A$. belgicae that appear similar to the Scottish specimens in terms of placoid morphology and claw morphology.

The Scottish specimens have a smooth cuticle and lack eyespots. One individual (body length $400 \mu \mathrm{m}$ ) was suitable for selected measurements. The buccal tube external diameter is $2.5 \mu \mathrm{m}$ and the total length of the buccal-pharyngeal tube is $30 \mu \mathrm{m}$. The pharynx contains two elongate rod-shaped macroplacoids, the first is approximately half the length of the second. In one specimen just one of the second macroplacoids appears fragmented at the middle of its length. Such fragmentation of the macroplacoids was also reported by Guidetti et al. (1999). Conspicuous, triangular microplacoids are present. The septulum is absent. Obvious cuticular bars are present on the first three pairs of legs and placed adjacent to the internal double claw. Cuticular bars are absent on the fourth pair of legs.

The Scottish specimens were also compared with A. belgicae from Austfjordnes, Svalbard present in the collection at the Natural History Museum of Denmark (catalogue number: TAR-002923 (processed by R.M.K.)). The museum specimen from Svalbard also corresponds well to Richters' description. The external claws have long and thin primary branches $(22.8 \mu \mathrm{m}$ on leg pair III for the branch alone, and $31.4 \mu \mathrm{m}$ from branch tip to the claw base). The claws of the Austfjordnes specimen and the Scottish specimens have conspicuously broad basal sections (particularly on the external claws) and the internal divisions of the claw are as those observed by Dastych on the Polish specimens (Dastych, 1988: Fig. 120C). The presence or absence of cuticular bars could not be definitively confirmed for the Austfjordens specimen due to the condition of the cuticle.

It is possible that the descriptions by Bernard (1977) and Pilato \& Binda (1977) correspond to closely related taxa within a species complex. A. belgicae requires formal re-description on material from the type location on Svalbard. Additionally, the results of molecular studies by Bertolani et al. (2014) suggest polyphyly of Adropion Pilato, 1987. Upon future evaluation of morphological and molecular data some Adropion species may be subjects of taxonomic rearrangement.

Specimens described as belonging to "belgicaescoticum complex" were collected from beech leaf litter in the U.S.A and Italy (Guidetti et al., 1999; Guidetti \& Bertolani, 2001). A. belgicae was previously recorded from the leaf litter of several tree species in the U.S.A. (Nelson \& Bartels, 2007). This is the first record of the species for Scotland.

Adropion prorsirostre (Thulin, 1928)

Scotland: Battle Hill, four adults; Invermoriston, four adults; Slug Road, seven adults.

The identification of the specimens was confirmed by comparison with the original type series of Thulin (1928), which consist of both Scottish and German examples (NHMD catalogue numbers: TAR-000776, TAR-000777).

Adropion prorsirostre has previously been recorded in beech leaf litter from Roan Mountain, U.S.A. (Guidetti et al., 1999).

Adropion scoticum scoticum (Murray, 1905a)

Ireland: Barna Woods: B2, three adults; B8, one adult. Scotland: Battle Hill, 32 adults; Fochabers, 19 adults; Invermoriston, 6 adults; Lake of Menteith, 1 adult; Slug Road, 3 adults.

All specimens conform to the original description by Murray (1905a), and are in agreement with the discussion of the species by Pilato (1974) and the subsequent account of British and Irish material of 
Morgan \& King (1976). Many of the larger specimens exhibit a light brown colouration of the cuticle.

This species has been recorded from "deciduous" and bracken (Pteridium spp.) leaf litter at Bookham Common, Surrey, England (Greaves, 1991; Greaves \& Marley, 1994), beech leaf litter from Denmark (Hallas \& Yeates, 1972) and the northern Apennines of Italy (Bertolani \& Rebecchi, 1996), and from the litters of several tree species in various localities (Iharos 1967, 1973; Guil \& Sánchez-Moreno, 2013).

Astatumen trinacriae (Arcidiacono, 1962)

Scotland: Battle Hill, five adults; Invermoriston, three adults; Slug Road, one adult.

The collected specimens correspond well to the original description of the species by Arcidiacono (1962). A. trinacriae has been previously recorded from beech leaf litter collected on Roan Mountain, U.S.A., and from the northern Apennines, Italy (Guidettti et al., 1999; Guidetti \& Bertolani, 2001). The North American and Italian populations were reported to differ by the presence of cuticular bars between the claws of all leg pairs only of the former population. Ciobanu \& Kaczmarek (2012) recorded A. trinacriae from Romania that exhibit cuticular bars adjacent to the claws of legs pairs I-III. While the original species description does not specify either the presence or absence of cuticular bars, Ramazzotti \& Maucci (1983) state that cuticular bars are present on either leg pair II or III and that Maucci observed an Italian population composed both of individuals with cuticular bars and those without bars. The Scottish specimens lack cuticular bars on all leg pairs. These observations of the variation of this character further support the suggestion by Kaczmarek \& Roszkowska (2016) of the presence of a species complex associated with $A$. trinacriae.

Itaquascon cf. globuliferum Abe \& Ito, 1994

Irish location: Barna Woods: B9, one adult.

Although only a single adult was obtained, the Irish specimen was determined to correspond closely to the original species description by Abe \& Ito (1994). The cuticle is generally smooth but granulation is present dorsally and is arranged in faint, irregular elongated patches. Eyes are absent. The spiral thickenings of the flexible portion of the buccal-pharyngeal are only faintly visible with DIC, but are more evident with $\mathrm{PhC}$. The pharyngeal bulb has a spherical appearance and contains placoids. Morphometrics of the Irish specimen for body length $(204.4 \mu \mathrm{m})$, maximum body width $(59.2 \mu \mathrm{m})$, length of buccal-pharyngeal tube (total length = $34.7 \mu \mathrm{m}$; rigid portion $=15.5 \mu \mathrm{m}$; flexible portion $=$ $19.2 \mu \mathrm{m})$, external width of buccal tube $(1.7 \mu \mathrm{m})$, length of bulb $(17.3 \mu \mathrm{m})$, width of bulb $(16.5 \mu \mathrm{m})$, length of placoids $(5.1,5.0$, and $5.0 \mu \mathrm{m})$, are similar to those given for the type population (Abe \& Ito, 1994) and result in closely comparable $p t$ values. The stylet insertion point on the buccal tube was not recorded for the type population, but for the Irish specimen $=14.4 \mu \mathrm{m}$.

The morphology of the claws matches the description by Abe \& Ito (1994) in having expanded bases without lunulae or dentition and two accessory points, but measurements were not provided for the type population. For the Irish example, the external primary branch height of the claw of leg pair I is $8.7 \mu \mathrm{m}$ and that of the posterior claw of leg pair IV is $10.2 \mu \mathrm{m}$. The original species description states that cuticular bars associated with claws are not present. However, Guidetti et al. (1999) reported the presence of cuticular bars on all legs of specimens of I. globuliferum collected from Roan Mountain, Tennessee, U.S.A. The same authors also reported the presence of cuticular bars on leg pairs I-III of a paratype specimen they examined. The Irish specimen has clear cuticular bars on legs I-III adjacent to the internal claw base and between the claws of leg pair IV. Open nomenclature must be used for this specimen due to the presence of the bar on leg pair IV that was not included in the original description or in the report on the examination of the paratype by Guidetti et al. (1999).

In addition to the type population from Japan and the North American population reported by Guidetti et al. (1999), I. globuliferum was also reported from a second Japanese location by Ito \& Abe (2001). This is the first record of the species and the genus from Ireland.

\section{Mesocrista indet.}

Scotland: Slug Road, one adult.

Gąsiorek et al. (2016) revised Mesocrista and distinguished between $M$. spitzbergensis (Richters, 1903) and a new similar species, M. revalata Gąsiorek, Stec, Morek, Zawierucha, Kaczmarek, LachowskaCierlik \& Michalczyk, 2016. Those authors concluded that previous records of $M$. spitzbergensis should be reconsidered as some may actually represent $M$. revalata. The Scottish Mesocrista specimen was not of satisfactory condition to allow for the distinction between these two taxa. "Mesocrista spitzbergensis" has been reported throughout the U.K. (e.g. Murray, 1905a; Greaves, 1991; Natress et al., 2014) and from Kilsallah, Co. Mayo, Ireland (Le Gros, 1959). Le Gros' (1959) record lacks a description of the specimen so the status of the species in Ireland cannot be considered certain. Due to the poor quality of the Scottish specimen it was not possible to re-evaluate the status of these previous records of $M$. spitzbergensis.

Subfamily Pilatobiinae Bertolani, Guidetti, Marchioro, Altiero, Rebecchi \& Cesari, 2014

Pilatobius bullatus (Murray, 1905a)

Ireland: Barna Woods: B1, two adults; B5, one adult; B8, four adults.

All specimens fit within the brief description by Murray (1905a) from the type locality at Loch Leven, Scotland. $P$. bullatus requires a formal re-description to include the modern taxonomic criteria because the original material probably does not exist (van der Land, 1966). Accounts of the species from Canada by Argue (1974) and Poland by Dastych (1988) provide greater detail than the original description, but these were based upon specimens collected at considerable distance from the locus typus. The Irish specimens are in particularly close agreement to the Polish examples of Dastych, having eight dorsal gibbosities arranged in two longitudinal 
rows, rounded or polygonal granulation (typically 1.1-2.2 $\mu \mathrm{m}$ in diameter) of the dorsal cuticle and gibbosities forming a vague mesh pattern, placoids of similar morphology and length, and stumpy claws with a cuticular bar present on the legs of pairs I-III and two cuticular bars on the legs of pair IV, each bar positioned laterally to each claw.

One specimen similarly matching the above-mentioned descriptions was also reported from moss on soil by Zawierucha et al. (2014) from Latvia. The species was previously recorded from beech leaf litter in Denmark (Hallas \& Yeates, 1972) and Italy (Guidetti et al., 1999) and from leaf litter in New Guinea (Iharos, 1973).

Pilatobius ramazzottii (Robotti, 1970)

Scotland: Leith Hall, four adults.

All specimens accord well with the description of the species by Robotti (1970) in terms of specific characters. These characters include: a finely granulated dorsal cuticle, pharyngeal bulb with prominent apophyses, two macroplacoids (centrally constricted macroplacoid 1 is longer than 2, macroplacoid 2 has a small caudal projection) and septulum, legs each with a bilobed gibbosity, and the presence of a cuticular bar originating from near the base of the internal claw on leg pairs I-III. While Robotti (1970) specifically stated that the species lacks accessory points on the claws, Pilato \& Binda (1977) observed thin accessory points upon the examination of a paratype and refined the species description to include this trait. The Scottish specimens exhibit inconspicuous accessory points on the primary branches of all claws (visible at magnifications greater than $\mathrm{x} 60)$.
Structural measurements were chosen following Robotti (1970) for comparative purposes (Table 3). The original species description provided morphometrics for a single representative individual. The calculated $p t d$ values for the data of the type specimen are close to those of the Scottish examples but the range of the morphometric data of the type population is unknown. Lisi et al. (2014) provided morphometric data for a paratype of P. ramazzottii to which the Scottish specimens were also compared in order to confirm the identification.

Pilatobius ramazzottii has been recorded from beech leaf litter from Italy and the U.S.A. (Guidetti et al., 1999). This is the first record of the species for Scotland.

Family Ramazzottiidae Sands, McInnes, Marley, Goodall-Copestake, Convey \& Linse, 2008

\section{Ramazzottius indet.}

Scotland: Battle Hill, one adult.

Because species identifications within the genus Ramazzottius Binda \& Pilato, 1986 typically require the observation of multiple adults and the egg (Biserov, 1997/98), a more precise identification of the Scottish specimens was not possible.

"Ramazzottius oberhaeuseri" (Doyère, 1840) has been recorded from leaf litter (Guidetti \& Bertolani, 2001; Nelson \& Bartels, 2007; Guil \& Sánchez-Moreno, 2013). However, Stec et al. (2018) re-described $R$. oberhaeuseri and identified additional species forming a cryptic complex. Therefore, past records for 'Ramazzottius oberhauseri' should be re-examined. Additionally, an unidentified Ramazzottius species was recorded in leaf litter from Texas (Hinton et al., 2014).

\begin{tabular}{|c|c|c|c|c|c|c|c|}
\hline \multirow[b]{2}{*}{ Character } & \multirow[b]{2}{*}{$\mathbf{n}$} & \multicolumn{3}{|c|}{$\mu \mathrm{m}$} & \multicolumn{3}{|c|}{$p t d$} \\
\hline & & Range & Mean & SD & Range & Mean & SD \\
\hline Body length & 4 & $289-355$ & 317 & 28 & $1340-1840$ & 1570 & 243 \\
\hline Buccal tube length & 4 & $19.3-22.8$ & 21.9 & 1.7 & - & - & - \\
\hline Pharyngeal tube length & 4 & $46.0-55.1$ & 48.9 & 4.4 & $200.6-285.2$ & 242.8 & 41.8 \\
\hline Stylet support insertion point & 4 & $13.7-16.9$ & 15.0 & 1.4 & $63.9-74.4$ & 68.6 & 5.0 \\
\hline Buccal tube internal width & 4 & $1.4-1.8$ & 1.6 & 0.2 & $6.6-8.9$ & 7.7 & 1.0 \\
\hline Macroplacoid 1 length & 4 & $5.3-7.1$ & 6.5 & 0.8 & $28.9-36.8$ & 32.0 & 3.4 \\
\hline Macroplacoid 2 length & 4 & $4.2-5.4$ & 4.8 & 0.5 & $20.6-27.9$ & 23.5 & 3.4 \\
\hline Septulum length & 4 & $2.3-2.8$ & 2.6 & 0.2 & $9.9-13.9$ & 12.9 & 2.3 \\
\hline $\begin{array}{l}\text { External claw pair I primary branch } \\
\text { length } \\
\text { External claw pair II primary branch }\end{array}$ & 2 & $11.4-14.0$ & 12.7 & 1.8 & $50.1-72.5$ & 61.3 & 15.8 \\
\hline $\begin{array}{l}\text { length } \\
\text { External claw pair III primary }\end{array}$ & 3 & $12.8-14.3$ & 13.5 & 0.8 & $62.7-79.2$ & 69.4 & 8.7 \\
\hline branch length & 2 & $12.9-13.9$ & 13.4 & 0.7 & $56.6-82.1$ & 69.4 & 18.0 \\
\hline $\begin{array}{l}\text { Posterior claw pair IV primary } \\
\text { branch length }\end{array}$ & 4 & $13.1-15.2$ & 13.5 & 1.6 & $57.6-78.7$ & 66.5 & 9.1 \\
\hline
\end{tabular}

Table 3. Selected morphometric data for Scottish Pilatobius ramazzottii specimens. n, number of individuals measured; $p t d$, ptd index; $\mathrm{SD}$, standard deviation. 
Order Isohypsibioidea Guil, Jørgensen \& Kristensen, 2019

Family Isohypsibiidae Sands, McInnes, Marley, Goodall-Copestake, Convey \& Linse, 2008

Isohypsibius prosostomus (Thulin, 1911)

Ireland: Barna Woods: B2, one adult; B8, one adult.

Scotland: Slug Road, two adults.

The identification of the specimens was confirmed by examination of the original type material (NHMD catalogue numbers: TAR-000662, TAR-000663) and description by Thulin (1911).

Previously the species has been recorded from Danish beech leaf litter (Hallas \& Yeates, 1972) and from the litters of several tree species in Spain (Guil \& SánchezMoreno, 2013).

Dianea sattleri (Richters, 1902)

Ireland: Barna Woods: B1, six adults; B4, one adult; B5, one adult; B6, three adults; B8, 11 adults; B9, four adults; B10, one adult.

All Irish specimens correspond to Dastych's (1991) re-description of the species (previously Isohypsibius sattleri Richters, 1902). Globally Dianea sattleri is a commonly recorded taxon but it likely represents a complex of similar species (Kaczmarek \& Roszkowska, 2016). It has previously been recorded from Italian beech litter (Bertolani \& Rebecchi, 1996), from leaf litter of New Guinea (Iharos, 1967) and from the litter of multiple tree species in Spain (Guil \& SánchezMoreno, 2013).

\section{Ursulinius sp. nov.}

Ireland: Barna Woods: B2, one adult; B3, two adults; B4, one adult.

The Irish specimens are similar in general appearance to Ursulinius ronsisvallei (Binda \& Pilato, 1969), which was also described from beech litter (Italy) as Isohypsibius ronsisvallei. However, the conformation of the dorsal gibbosities differs from that of $U$. ronsisvallei, as well as from that of all other described species as determined by a comparison of all such species descriptions. The Irish specimens have: pigmented eye spots, two rod shaped macroplacoids, a partially reticulated cuticle with a unique arrangement of dorsal gibbosities in ten transverse rows (formula = [2-3-4-3-4-3-4-2-2-3]), two gibbosities on each leg, and a cuticular bar that is unlike that of $U$. ronsisvallei in terms of orientation with respect to the claws. This taxon will be described in a separate paper.

Order Macrobiotoidea Thulin, 1928 Family Macrobiotidae Thulin, 1928

\section{Macrobiotus hufelandi group indet.}

Ireland: Barna Woods: B1, two adults; B2, two adults; B4, one adult; B6, one adult; B8, 21 adults; B9, two adults.

Scotland: Battle Hill, two adults; Lake of Menteith, seven adults; Leith Hall, two adults; Slug Road, four adults.
Precise identifications of taxa within this species complex typically require observation of the egg (Bertolani \& Rebecchi, 1993). No eggs belonging to the "hufelandi group" were observed from the Irish or Scottish samples. As a result, the species level identity of the specimens was indeterminable. This taxonomically difficult group was reviewed by Kaczmarek \& Michalczyk (2017). Following the updated criteria and terminology used for the group by those authors all adult specimens recovered from both Irish and Scottish leaf litter can be described as having hufelandi type oral cavity armature along with hufelandi type claws and smooth cuticles with pores. The number of hufelandi group species present among the samples could not be determined.

\section{Mesobiotus harmsworthi group sp.}

Ireland: Barna Woods: B2, six adults; B3, four adults; B4, three adults; B5, four adults, four eggs; B6, eight adults; B7, two adults; B8, 18 adults, ten eggs; B9, three adults; B10, two adults

Scotland: Battle Hill, three adults; Invermoriston, 23 adults, nine eggs.

The adults of the Irish and Scottish populations are morphologically indistinguishable from each other and belong to the "Mesobiotus harmsworthi group". Mesobiotus harmsworthi (Murray, 1907) is the nominal species of a complex in which eggs are important for identifying taxa. Mesobiotus harmsworthi harmsworthi has been recently re-described by Kaczmarek et al. (2018). Those authors clarified the description of the egg morphology for Mesobiotus harmsworthi, which had become confused throughout previous decades of varying reports. While a total of 23 eggs was collected in the present survey, none of these matched well to the re-described harmsworthi egg or precisely to the descriptions of the eggs of any known species of the group. However, it could not be positively determined if the collected eggs fall within the range of variation for other Mesobiotus species that require modern re-descriptions, or if they represent a new species. For this reason, open nomenclature is used to designate the presence of at least one other Mesobiotus species in Scotland and Ireland that is not M. h. harmsworthi. This is not considered as a new taxon record for either country as the status of all records for the taxon made prior to the re-description are also reset to unidentified species of the harmsworthi group (Kaczmarek et al., 2018).

\section{Minibiotus sp. nov.}

Ireland: Barna Woods: B8, two adults.

Two specimens belonging to the genus Minibiotus R.O. Schuster, 1980 were retrieved from Barna Woods. These specimens possess 11 distinct transverse bands of round cuticular pores. The specimens are clearly different from Minibiotus intermedius (Plate, 1888), the only other species of the genus thus far recorded from Ireland and Scotland, which lacks cuticular pores entirely. The Irish specimens from Barna Woods could not be assigned a species identity from among the other known congeners most due to a unique combination of cuticular pore morphology and distribution, and the macroplacoid 
length sequence. Morphologically similar specimens ascribable to this same taxon have been collected from another location in Scotland by one of the present authors. These have been determined to represent a new species, which is in the process of formal taxonomic description in collaboration with that author (B.B.) and another research group (Daniel Stec, pers. comm., November 2019).

Paramacrobiotus cf. richtersi (Murray, 1911a)

Ireland: Barna Woods: B1, two adults; B3, three adults, two eggs; B4, 20 adults, four eggs; B5, 29 adults, four eggs; B6, nine adults, two eggs; B8, 67 adults, 11 eggs; B9, five adults.

Scotland: Battle Hill, eight adults, 12 eggs; Fochabers, 24 adults; Invermoriston, seven adults, eight eggs; Lake of Menteith: 18 adults, five eggs; Leith Hall: three adults, two eggs.

Paramacrobiotus Guidetti, Schill, Bertolani, Dandekar \& Wolf, 2009 has undergone recent revision (Kaczmarek et al., 2017b; Marley et al., 2018) with further detailed investigation of the $P$. richtersi complex and a re-description of the nominal species by Guidetti et al. (2019). P. richtersi (as "Macrobiotus richtersi") was described by Murray (1911a) from moss from Clare Island, Ireland. In his description Murray included an unnamed variety differing in the morphology of the egg. The eggs found among the Irish and Scottish beech litters exhibit internally sculpted areoles with reticulated processes and are of the "richtersi type" as defined by Kaczmarek et al. (2018). However, the collected eggs exhibit variation in several features. This variation, sometimes between the morphologies of processes on the same egg, complicated the species identification. Egg processes were observed with rounded and bluntly pointed cone shapes of varying dimensions (both width and height), with or without additional papillate structures at the cone apices, and varying in the number of processes per hemisphere. The adults of the Scottish and Irish populations are morphologically similar in the buccal armature and possess three macroplacoids and a microplacoid. However, various patterns of distribution of granulation on the leg pairs were observed.

Although $P$. richtersi has been recently re-described by Guidetti et al. (2019) and the specimens in the present study originate geographically near to the type locality, open nomenclature for these specimens is used pending a further study involving integrative molecular and morphological data in order to elucidate the extent of species richness within the $P$. richtersi complex in Ireland and Scotland.

Family Murrayidae Guidetti, Rebecchi \& Bertolani, 2000

Murrayon hibernicus (Murray, 1911a)

Ireland: Barna Woods: B8, one egg.

A single egg conforming to the description given by Murray (1911a) of the type material from Achill Island, Ireland (Murray, 1911a) was collected.
Murrayon hibernicus has not previously been recorded from leaf litter (Guil \& Sánchez- Moreno, 2013), though an undescribed species of the genus was reported from leaf litter in Texas by Hinton et al. (2014).

\section{DISCUSSION}

The present study is the first report on the tardigrade species associated with the leaf litter microhabitat in Ireland and Scotland. Although the study was not intended as a quantitative ecological investigation, some new information concerning leaf litter-inhabiting tardigrades was gained. All samples were positive for tardigrades with the abundances of individuals being generally low (mean $=32$ adult individuals per sample $(\mathrm{N}=16)$ ). Although few samples were included, several tardigrade taxa not previously known from these countries were recovered. In Ireland these were Pseudechiniscus sp. nov, Diphascon pingue group sp., Hypsibius cf. convergens, Hypsibius cf. scabropygus, Itaquascon cf. globuliferum, Ursulinius sp. nov., and Minibiotus sp. nov. The taxa newly discovered in Scotland were Bertolanius weglarskae, Hypsibius cf. scabropygus, Adropion belgicae and Pilatobius ramazzottii. Itaquascon cf. globuliferum and Bertolanius weglarskae represent the first records for their genera in the respective countries.

Thirteen of the 25 taxa collected in the present study required the use of open nomenclature. Of these, three taxa (of the genera Pseudechiniscus, Ursulinius, and Minibiotus) exhibited characters that separate each from the descriptions of any known species and were determined to represent new species, designated as sp. nov., to be described in separate papers. Open nomenclature was necessary for ten other taxa for various reasons: (1) the taxa exhibited a trait or traits not included in the original species description (Hypsibius cf. convergens, Hypsibius cf. scabropygus, Itaquascon cf. globuliferum); (2) the taxa belong to species complexes that require more data to make precise identifications than were collected (Diphascon pingue group sp., Hypsibius cf. dujardini, Mesobiotus harmsworthi group sp. and Paramacrobiotus cf. richtersi.); (3) species level identification was indeterminable because either eggs belonging to the taxa were not observed (Ramazzottius indet. and Macrobiotus hufelandi group indet.); or (4) the necessary characters for identification were not sufficiently preserved (Mesocrista indet.). This frequent employment of open nomenclature reflects a general change in tardigrade taxonomy in the modern era with the recognition of morphologically similar species complexes and cryptic taxa, many of which have been considered to be of cosmopolitan distribution in the past, and the need for integrative analysis to support identifications of such taxa (Gąsiorek et al., 2018; Guidetti et al., 2019). In such cases, a cautious approach is necessary when creating new species distribution records.

The species identities of some of the collected taxa could have been confirmed by the inclusion of molecular data, as some of these species have been recently re-described 
using integrative methodologies: H. dujardini (Gąsiorek et al., 2018), Mesocrista spp. (Gąsiorek et al., 2016), and Paramacrobiotus richtersi (Guidetti et al., 2019). While some molecular data are available for the Diphascon pingue, Ramazzottius oberhaeuseri, Macrobiotus hufelandi and Mesobiotus harmsworthi groups (see e.g. Bertolani et al., 2014; Stec et al., 2018; Kaczmarek \& Michalczyk, 2017; Kaczmarek et al., 2018), sequences have not yet been obtained for many of the known species within these complexes, thus molecular data for the collected specimens belonging to these groups would not necessarily enable assignment to a known species or confirmation of new species status for the Diphascon pingue group sp. The resolution of the species identities of $H$. cf. convergens, $H$. cf. scabropygus, and Itaquascon cf. globuliferum, would be best facilitated by clarification of the morphological characters of the type populations via species re-descriptions or emendations.

There was some overlap in the collected taxa of the two countries with 8/25 found in both Irish and Scottish beech leaf litter (Table 1). Although Mesocrista spp. and Murrayon hibernicus have not been previously reported from leaf litter from any locality, Morgan (1980) reported "Mesocrista spitzbergensis" to be associated with soil collected in Iceland. Of the other taxa collected in the present study Diphascon pingue pingue, Adropion belgicae, Adropion prorsirostre, Adropion scoticum scoticum, Astatumen trinacriae, Pilatobius bullatus, Isohypibius prosostomus, Dianea sattleri and Macrobiotus hufelandi group sp. as well as the nominal taxa of species complexes Hypsibius convergens and H. dujardini, are also known to occur in European soils (Bingemer \& Hohberg, 2017; and references therein). However, these taxa are also commonly collected from mosses and lichens and this may reflect generalist, rather than specialist, species ecologies.

In a study comparing richness and abundance of terrestrial tardigrades across multiple habitat types, Guil et al. (2009) found that leaf litter (along with mosses on rocks) contained exclusive species that did not occur in any of the other habitat types sampled. The recovery of at least three potentially new species and a total of 11 new distribution records for Ireland or Scotland from a small number of samples in the present study also indicates the importance of leaf litter as a microhabitat in determining the overall tardigrade biodiversity of an area. The new evaluation of extraction methods of tardigrades from leaf litter for quantitative studies by Czerneková et al. (2018) may be useful in facilitating more frequent inclusion of the leaf litter habitat in future ecological studies of tardigrades.

\section{ACKNOWLEDGEMENTS}

The authors wish to thank Professor Giovani Pilato of the University of Catania, Italy and Professor Roberto Guidetti of the University of Modena and Reggio Emilia, Italy for providing photomicrographs for comparative purposes that were helpful during the specimen identification process. The authors are also grateful to Laura Pavesi, Collections Manager
(Invertebrates), Natural History Museum of Denmark, for her assistance in accessing material in the museum collection, and to an anonymous reviewer for valuable suggestions concerning the manuscript. B.B. thanks Dr Łukasz Michalczyk of Jagiellonian University, Krakow, Poland, for provision of Hoyer's medium, and the Ecology Department, SEPA, Aberdeen, for the occasional use of their phase contrast microscope.

\section{REFERENCES}

Abe, W. \& Ito, M. (1994). Itaquascon globuliferum, a new species of Tardigrada (Eutardigrada: Hypsibiidae) from Japan. Proceedings of the Japanese Society of Systematic Zoology 51, 8-11.

Arcidiacono, R. (1962). Contributo alla conoscenza dei tardigradi dei Monti Nebrodi e descrizione di una nuova specie di Itaquascon. Bollettino delle Sedute dell' Accademia Gioenia di Scienze Naturali in Catania, Serie IV 7(3), 123-134.

Argue, C.W. (1974). Tardigrades from New Brunswick, Canada. 3. Canadian Journal of Zoology 52, 919922. https://doi.org/10.1139/z74-122

Beasley, C.W. \& Cleveland, A. (1996). Tardigrada from southern Yunnan Province, People's Republic of China. Zoological Journal of the Linnean Society 116, 239-243. https://doi.org/10.1111/j.1096-3642.1996.tb02346.x

Bernard, E.C. (1977). A new species of Hexapodibius from North America, with a redescription of Diphascon belgicae (Tardigrada). Transactions of the American Microscopical Society 96(4), 476-482. https://doi.org/10.2307/3225665

Bertolani, R. (1981). The taxonomic position of some eutardigrades. Bollettino di Zoologia 48, 197-203. https://doi.org/10.1080/11250008109439334

Bertolani, R. (1982). Tardigradi (Tardigrada). Guide per il Riconoscimento delle Specie Animali delle Acque Interne Italiane 15. Consiglio Nazionale delle Ricerche, Verona.

Bertolani, R., Guidetti, R., Altiero, T., Nelson, D.R. \& Rebecchi, L. (2019). Dormancy in freshwater tardigrades. In: Alekseev, V.R. \& Pinel-Alloul, B. (Editors). Dormancy in Aquatic Organisms. Theory, Human Use and Modelling. Monographiae Biologicae Vol. 92, pp. 43-51. Springer, Cham. https://doi.org/10.1007/978-3-030-21213-1_3

Bertolani, R., Guidetti, R., Marchioro, T., Altiero, T., Rebecchi, L. \& Cesari, M. (2014). Phylogeny of Eutardigrada: new molecular data and their morphological support lead to the identification of new evolutionary lineages. Molecular Phylogenetics and Evolution 76, 110-126. https://doi.org/10.1016/j.ympev.2014.03.006

Bertolani, R. \& Kinchin, I.M. (1993). A new species of Ramazzottius (Tardigrada, Hypsibiidae) in a rain gutter sediment from England. Zoological Journal of the Linnean Society 109, 327-333.

https://doi.org/10.1111/j.1096-3642.1993.tb02538.x

Bertolani, R. \& Kristensen, R.M. (1987). New records of Eohypsibius nadjae Kristensen, 1982, and revision of the taxonomic position of two genera of Eutardigrada (Tardigrada). In: Bertolani, R. (Editor). 
Biology of Tardigrades. Selected Symposia and Monographs U.Z.I. Vol. 1, pp. 359-372. Mucchi, Modena.

Bertolani, R. \& Rebecchi, L. (1993). A revision of the Macrobiotus hufelandi group (Tardigrada, Macrobiotidae), with some observations on the taxonomic characters of Eutardigrades. Zoologica Scripta 22(2), 127-152. https://doi.org/10.1111/j.1463-6409.1993.tb00347.x

Bertolani, R. \& Rebecchi, L. (1996). The Tardigrades of Emilia (Italy). II. Monte Rondinaio. A multihabitat study on high altitude valley of the northern Apennines. Zoological Journal of the Linnean Society 116, 3-12. https://doi.org/10.1111/j.1096-3642.1996.tb02329.x

Bingemer, J. \& Hohberg, K. (2017). An illustrated identification key to the eutardigrade species (Tardigrada, Eutardigrada) presently known from European soils. Soil Organisms 89(3), 127-149.

Biserov, V.I. (1997/98). Tardigrades of the Caucasus with a taxonomic analysis of the genus Ramazzottius (Parachela: Hypsibiidae). Zoologischer Anzeiger 236, 139-159.

Cesari, M., Montanari, M., Kristensen, R.M., Bertolani, R., Guidetti, R. \& Rebecchi, L. (2019). An integrated study of the biodiversity within the Pseudechiniscus suillus-facettalis group (Heterotardigrada: Echiniscidae). Zoological Journal of the Linnean Society. http://dx.doi.org/10.1093/zoolinnean/zlz045.

Ciobanu, D.A. \& Kaczmarek, Ł. (2012). The eutardigrade genus Astatumen (Parachela: Hypsibiidae: Itaquasconinae), new to Romania. Analele Ştiințifice ale Universității Alexandru Ioan Cuza din Iași, s. Biologie Animală 58, 205-208.

Ciobanu, D.A., Moglan, I., Zawierucha, K. \& Kaczmarek, Ł. (2014). New records of terrestrial tardigrades (Tardigrada) from Ceahlău National Park with zoogeographical and taxonomical remarks on Romanian water bears. North-western Journal of Zoology 10(Suppl. 1), S5-S21.

Cuénot, L. (1929). Description d'un tardigrade nouveau de la faune francaise. Archives d'anatomie Microscopique 25, 121-125.

Czerneková, M., Jönsson, K.I., Hajer, J. \& Devetter, M. (2018). Evaluation of extraction methods for quantitative analysis of tardigrade populations in soil and leaf litter. Pedobiologia- Journal of Soil Ecology $70,1-5$. https://doi.org/10.1016/j.pedobi.2018.06.005

Dastych, H. (1972). Isohypsibius weglarskae sp. n. a new species of Tardigrada from Poland. Bulletin de L'Academie Polonaise des Sciences 20(11), 761762.

Dastych, H. (1988). The Tardigrada of Poland. Monografie Fauny Polski Vol. 16. Institute of Systematics and Evolution of Animals, Polish Academy of Sciences, Kraków, Poland.

Dastych, H. (1991). Isohypsibius sattleri (Richters, 1902), a valid species (Tardigrada). Senckenbergiana Biologica 71(1/3), 181-189.

Degma, P. \& Guidetti, R. (2007). Notes to the current checklist of Tardigrada. Zootaxa 1579, 41-53.
Degma, P., Bertolani, R. \& Guidetti, R. (2019). Actual checklist of Tardigrada species (2009-2019, Ver. 35: 31-07-2019). https://doi.org/10.11646/zootaxa.1579.1.2

DeMilio, E., Lawton, C. \& Marley, N.J. (2016). Tardigrada of Ireland: a review of records and an updated checklist of species including a new addition to the Irish fauna. ZooKeys 616, 77-101. https://doi.org/10.3897/zookeys.616.8222

DeMilio, E., Marley, N.J., Lawton, C. \& Kristensen, R.M. (in press). Tardigrada of Clare Island. In: Breem, J. \& McCarthy, T.K. (Editors). New Survey of Clare Island Volume [?]: Animals. Royal Irish Academy, Dublin.

Fontoura, P. \& Pilato, G. (2007). Diphascon (Diphascon) faialense sp. nov. a new species of Tardigrada (Eutardigrada, Hypsibiidae) from the Azores and a key to the species of the D. pingue group. Zootaxa 1589, 47-55. https://doi.org/10.11646/zootaxa.1589.1.4

Gąsiorek, P., Stec, D., Morek, W. \& Michalczyk, Ł. (2018). An integrative redescription of Hypsibius dujardini (Doyère, 1840), the nominal taxon for Hypsibioidea (Tardigrada: Eutardigrada). Zootaxa 4415(1), 45-75. https://doi.org/10.11646/zootaxa.4415.1.2

Gąsiorek, P., Stec, D., Morek, W., Zawierucha, K., Kaczmarek, Ł., Lachowska-Cierlik, Ł. \& Michalczyk, Ł. (2016). An integrative revision of Mesocrista Pilato, 1987 (Tardigrada: Eutardigrada: Hypsibiidae). Journal of Natural History 50, 28032828. https://doi.org/10.1080/00222933.2016.1234654

Greaves, P.M. (1991). Notes on the tardigrade fauna of Surrey. Microscopy 36, 549-556. https://doi.org/10.1007/BF02884035

Greaves, P.M. \& Marley, N.J. (1994). The tardigrade fauna of Bookham Common. The London Naturalist 73, 185-190.

Guidetti, R. Altiero, T, Bertolani, R., Pasqualina, G. \& Rebecchi, L. (2011). Survival of freezing by hydrated tardigrades inhabiting terrestrial and freshwater habitats. Zoology 114, 123-128. https://doi.org/10.1016/j.zool.2010.11.005

Guidetti, R. \& Bertolani, R. (2001). The tardigrades of Emilia (Italy). III. Piane di Mocogno (Northern Apennines). Zoologischer Anzeiger 240, 377-383. https://doi.org/10.1078/0044-5231-00045

Guidetti, R. \& Bertolani, R. (2005). Tardigrade taxonomy: an updated check list of the taxa and a list of characters for their identification. Zootaxa 845, 146. https://doi.org/10.11646/zootaxa.845.1.1

Guidetti, R., Bertolani, R. \& Nelson, D.R. (1999). Ecological and faunistic studies on tardigrades in leaf litter of beech forest. Zoologischer Anzeiger 238, 215-223.

Guidetti, R., Cesari, M., Bertolani, R., Altiero, T. \& Rebecchi, L. (2019). High diversity in species, reproductive modes and distribution within the Paramacrobiotus richtersi complex (Eutardigrada, Macrobiotidae). Zoological Letters 5(1), 1-28. https://doi.org/10.1186/s40851-018-0113-z 
Guil, N. (2008). New records and within-species variability of Iberian tardigrades (Tardigrada), with comments on the species from the Echiniscus blumicanadensis series. Zootaxa 1757, 1-30. https://doi.org/10.11646/zootaxa.1757.1.1

Guil, N., Hortal, J., Sánchez-Moreno, S. \& Machordom, A. (2008). Effects of macro-environmental factors on the species richness of terrestrial tardigrade assemblages in an Iberian mountain environment. Landscape Ecology 24, 375-390. https://doi.org/10.1007/s10980-008-9312-x

Guil, N. \& Sánchez-Moreno, S. (2013). Fine-scale patterns in micrometazoans: tardigrade diversity, community composition and trophic dynamics in leaf litter. Systematics and Biodiversity 11(2), 181193. https://doi.org/10.1080/14772000.2013.798370

Guil, N., Sánchez-Moreno, S. \& Machordom, A. (2009). Local biodiversity patterns in micrometazoans: are tardigrades everywhere? Systematics and Biodiversity 7, 259-268. https://doi.org/10.1017/S1477200009003016

Hallas, T.E. \& Yeates, G.W. (1972). Tardigrada of the soil and litter of a Danish beech forest. Pedobiologia 12, 287-304.

Hansen, J.G. \& Katholm, A.K. (2002). A study of the genus Amphibolus from Disko Island with special attention on the life cycle of Amphibolus nebulosus (Eutardigrada: Eohypsibiidae). In: Hansen, J.G. (Editor). Arctic Biology Field Course. Qeqertarsuaq 2002, pp. 129-163. Zoological Museum University of Copenhagen, Copenhagen, Denmark.

Hansen J.G., Kristensen, R.M., Bertolani, R. \& Guidetti, R. (2016). Comparative analyses of Bertolanius species (Eohypsibiidae; Eutardigrada) with the description of Bertolanius birnae sp. nov. from northern polar regions. Polar Biology 40(1), 123140.

https://doi.org/10.1007/s00300-016-1931-0

Hinton, J.G. \& Meyer, H.A. (2007). Distribution of limnoterrestrial Tardigrada in Georgia and the Gulf Coast states of the United States of America with ecological remarks. Journal of Limnology 66(Suppl. 1), $72-76$. https://doi.org/10.4081/jlimnol.2007.s1.72

Hinton, J.G., Meyer, H.A., McDaniel, N.D., Bergeron, C.B., Keely, S.J. \& Matte, A. (2014). Lone star bears: the Tardigrada of Big Thicket National Preserve, Texas. Proceedings of the $5^{\text {th }}$ Big Thicket Science Conference: Changing Landscapes and Changing Climate, Southeastern Naturalist 13(Special Issue 5), 131-136. https://doi.org/10.1656/058.013.s512

Hinton. J.G., Meyer, H.A. \& Sweeney, A.W. (2010). Seasonal and spatial variation in diversity and abundance of tardigrades in leaf litter from Louisiana and Florida. The Southwestern Naturalist 55(4), 539-543. https://doi.org/10.1894/JS-28.1

Hohberg, K. (2006). Tardigrade species composition in young soils and some aspects on life history of Macrobiotus richtersi J. Murray, 1911. Pedobiologia 50,267-274. https://doi.org/10.1016/j.pedobi.2006.02.004

Iharos, G. (1967). Beitrage zur Kenntnis der Tardigradenfauna von Neuguinea. Opuscula Zoologica Budapest 7, 113-135.

Iharos, G. (1973). Neuere Daten zur Kenntnis der Tardigradenfauna von Neuguinea. Opuscula Zoologica Budapest 11, 63-73.

Ito, M.T. \& Abe, W. (2001). Micro-distribution of soil inhabiting tardigrades (Tardigrada) in a sub-alpine coniferous forest of Japan. Zoologischer Anzeiger 240, 403-407. https://doi.org/10.1078/0044-5231-00048

Kaczmarek, Ł., Gawlak, M., Bartels, P.J., Nelson, D.R. \& Roszkowska, M. (2017b). Revision of the genus Paramacrobiotus Guidetti et al., 2009 with the description of a new species, re-descriptions and a key. Annales Zoologici 67(4), 627-656. https://doi.org/10.3161/00034541ANZ2017.67.4.00 1

Kaczmarek, Ł., Parnikoza, I., Gawlak, M., Esefeld, J., Peter, H., Kozeretska, I. \& Roszkowska, M. (2017a). Tardigrades from Larus dominicanus Lichtenstein, 1823 nests on the Argentine Islands (maritime Antarctic). Polar Biology 42(2), 283-301. https://doi.org/10.1007/s00300-017-2190-4

Kaczmarek, Ł. \& Michalczyk, Ł. (2009). Redescription of Hypsibius microps Thulin, 1928 and H. pallidus Thulin, 1911 (Eutardigrada: Hypsibiidae) based on the type material from the Thulin collection. Zootaxa 2275, 60-68. https://doi.org/10.11646/zootaxa.2275.1.4

Kaczmarek, Ł. \& Michalczyk, Ł. (2017). The Macrobiotus hufelandi group (Tardigrada) revisited. Zootaxa 4363(1), 101-123. https://doi.org/10.11646/zootaxa.4363.1.4

Kaczmarek, Ł. \& Roszkowska, M. (2016). A new eutardigrade from Costa Rica with taxonomical and zoogeographical remarks on Costa Rican tardigrades. New Zealand Journal of Zoology 43(3), 234-245. https://doi.org/10.1080/03014223.2016.1156553

Kaczmarek, Ł., Zawierucha, K., Buda, J., Stec, D., Gawlak, M., Michalczyk, Ł. \& Roszkowska, M. (2018). An integrative redescription of the nominal taxon for the Mesobiotus harmsworthi group (Tardigrada: Macrobiotidae) leads to descriptions of two new Mesobiotus species from Arctic. PLoS ONE 13(10), 1-43. https://doi.org/10.1371/journal.pone.0204756

Kinchin, I.M. (1994). The Biology of Tardigrades. Portland Press Ltd., London.

Le Gros, A.E. (1955). Some notes on the Tardigrada or water bears. North Western Naturalist 1955, 281290.

Le Gros, A.E. (1957). Tardigrades from southern Warwickshire. Reports of the Warwick Natural History Society 1957, 10-12.

Le Gros, A.E. (1959). Pseudechiniscus cornutus (Richters) and Hypsibius spitzbergensis (Richters), tardigrades new to Ireland. Irish Naturalists' Journal $13,44$.

Lisi, O. (2015). Current knowledge on the Sicilian tardigrade fauna. Biodiversity Journal 6(1), 297-304. 
Lisi, O., Sabella, G. \& Pilato, G. (2014). Mixibius parvus sp. nov. and Diphascon (Diphascon) ziliense sp. nov., two new species of Eutardigrada from Sicily. Zootaxa 3802(4), 459-468.

https://doi.org/10.11646/zootaxa.3802.4.3

Marley, N.J., Kaczmarek, Ł., Gawlak, M., Bartels, P.J., Nelson, D.R., Roszkowska, M., Stec, D. \& Degma, P. (2018). A clarification for the subgenera of Paramacrobiotus Guidetti, Schill, Bertolani, Dandekar and Wolf, 2009, with respect to the International Code of Zoological Nomenclature. Zootaxa, 4407(1), 130-144.

https://doi.org/10.11646/zootaxa.4407.1.9

McInnes, S.J. (1994). Zoogeographical distribution of terrestrial/freshwater tardigrades from current literature. Journal of Natural History 28, 257-352. https://doi.org/10.1080/00222939400770131

McInnes, S.J., Michalczyk, Ł. \& Kaczmarek, Ł. (2017). Annotated zoogeography of non-marine Tardigrada. Part IV: Africa. Zootaxa 4284(1), 1-74. https://doi.org/10.11646/zootaxa.4284.1.1

Meyer, H.A. (2015). Water bears (Phylum Tardigrada) of Oceania, with the description of a new species of Milnesium. New Zealand Journal of Zoology 42(3), 173-186. https://doi.org/10.1080/03014223.2015.1062402

Mihelčič, F. (1949). Nuevos biotopos de tardígrados. Contribución al conocimiento de la ecología de los tardígrados. Anales de Edafología y Fisiología Vegetal 8, 511-526.

Morek, W., Gąsiorek, P., Stec, D., Blagden, B. \& Michalczyk, Ł. (2016). Experimental taxonomy exposes ontogenetic variability and elucidates the taxonomic value of claw configuration in Milnesium Doyère, 1840 (Tardigrada: Eutardigrada: Apochela). Contributions to Zoology 85(2), 173-200. https://doi.org/10.1163/18759866-08502003

Morgan, C.I. (1976). Studies on the British tardigrade fauna: some zoogeographical and ecological notes. Journal of Natural History 10, 607-632. https://doi.org/10.1080/00222937600770491

Morgan, C.I. (1980). A systematic survey of tardigrada from Iceland. Acta Naturalia Islandica 27, 1-25.

Morgan, C.I. \& King, P.E. (1976). British Tardigrades. Synopses of the British Fauna (New Series) No. 9. Linnaean Society of London, Academic Press, London.

Murray, J. (1905a). The Tardigrada of the Forth Valley. Annals of Scottish Natural History 55, 160-164.

Murray, J. (1905b). The Tardigrada of Scottish lochs. Transactions of the Royal Society of Edinburgh 41, 677-698. https://doi.org/10.1017/S0080456800035547

Murray, J. (1906a). Scottish alpine Tardigrada. Annals of Scottish Natural History 57, 25-30.

Murray, J. (1906b). The Tardigrada of the Forth Valley II. Annals of Scottish Natural History 60, 214-217.

Murray, J. (1907). Scottish Tardigrada collected by the Lake Survey. Transactions of the Royal Society of Edinburgh 45, 641-668. https://doi.org/10.1017/S0080456800011777

Murray, J. (1911a). Arctiscoida. Proceedings of the Royal Irish Academy 31(37), 1-16.
Murray, J. (1911b). Scottish Tardigrada: a review of our present knowledge. Annals of Scottish Natural History 78, 88-95.

Nattress, B., Smith, M. \& Ramsbottom, J. (2014). Some records of tardigrades in Yorkshire. The Naturalist 139(1078), 167-171.

Nelson, D. (2002). Current status of Tardigrada: evolution and ecology. Integrative and Comparative Biology 42(3), 652-659. https://doi.org/10.1093/icb/42.3.652

Nelson, D. \& Bartels, P.J. (2007). 'Smoky bears Tardigrades of Great Smoky Mountains National Park. Southeastern Naturalist, Special issue 1, 229238.

https://doi.org/10.1656/1528-7092(2007)6[229:SB OGSM]2.0.CO;2

Nelson, D. \& Bartels, P.J. (2013). Species richness of soil and leaf litter tardigrades in the Great Smoky Mountains National Park (North Carolina/Tennessee, USA). Journal of Limnology 72(Suppl. 1), 144-151. https://doi.org/10.4081/jlimnol.2013.s1.e18

Nelson, D., Bartels, P.J. \& Guil, N. (2019). Tardigrade Ecology. In: Schill, R.O. (Editor). Water Bears: The Biology of Tardigrades. Zoological Monographs 2, pp. 163-210. Springer, Cham. https://doi.org/10.1007/978-3-319-95702-9_7

Pilato, G. (1974). Studio su Diphascon scoticum J. Murr., 1905 (Eutardigrada) e alcune altre specie ritenute ad esso affini. Animalia 1(1/3), 73-88.

Pilato, G. (1981). Analisi di nuovi caratteri nello studio degli Eutardigradi. Animalia 8, 51-7.

Pilato, G. \& Binda, M.G. (1977). Precisazioni e rettifiche alla descrizione di alcune specie di tardigradi (seconda nota). Animalia 4(1/2), 35-51.

Pilato, G. \& Binda, M.G. (1997/98). A comparison of Diphascon (D.) alpinum Murray, 1906, D. (D.) chilenense Plate, 1889 and $D$. (D.) pingue Marcus, 1936 (Tardigrada), and description of a new species. Zoologisher Anzeiger 236, 181-185.

Pilato, G. \& Binda, M.G. (1999). Three new species of Diphascon of the pingue group (Eutardigrada, Hypsibiidae) from Antarctica. Polar Biology 21, 335-342. https://doi.org/10.1007/s003000050370

Ramazzotti, G. \& Maucci, W. (1983). Il Phylum Tardigrada $\left(3^{\text {rd }}\right.$ edition, C.W. Beasley, English Translation). Memorie dell'Istituto Italiano di Idrobiologia 41, 1-1012.

Richters, F. (1911). Faune de mousees. Tardigrades. Duc d'Orleans Campagne Arctique de 1907 4, 1-20.

Robotti, C. (1970). Hypsibius (D.) ramazzottii spec. nov. e Macrobiotus aviglianae spec. nov. primo contributo alla conoscenza dei Tardigradi del Piemonte. Atti della Società Italiana di Scienze Naturali e del Museo Civico di Storia Naturale in Milano 110, 252-255.

Roszkowska, M., Ostrowska, M., Grobys, D., Kamita, H. \& Kaczmarek, Ł. (2019). Some tardigrades from Italy, with an updated checklist of limno-terrestrial species from the country. Acta Zoologica Bulgarica 71(2), 167-174. 
Sigovini, M., Keppel, E. \& Tagliapietra, D. (2016). Open nomenclature in the biodiversity era. Methods in Ecology and Evolution 7, 1217-1225. https://doi.org/10.1111/2041-210X.12594

Sømme, L. (1996). Anhydrobiosis and cold tolerance in tardigrades. European Journal of Entomology 93, 349-357.

Stec, D., Morek, W., Gąsiorek, P., Blagden, B. \& Michalczyk, Ł. (2017). Description of Macrobiotus scoticus sp. nov. (Tardigrada: Macrobiotidae: hufelandi group) from Scotland by means of integrative taxonomy. Annales Zoologici 67(2), 181197.

https://doi.org/10.3161/00034541ANZ2017.67.2.00 1

Stec, D., Morek, W., Gąsiorek, P. \& Michalczyk, Ł. (2018). Unmasking hidden species diversity within the Ramazzottius oberhaeuseri complex, with an integrative redescription of the nominal species for the family Ramazzottiidae (Tardigrada: Eutardigrada: Parachela). Systematics and Biodiversity 16(4), 357-376. https://doi.org/10.1080/14772000.2018.1424267

Thulin, G. (1911). Beiträge zur Kenntnis der Tardigraden Fauna Schwedens. Arkiv för Zoologi 7 , $1-60$. https://doi.org/10.5962/bhl.part.1270

Thulin, G. (1928). Über die Phylogenie und das System der Tardigraden. Hereditas 11, 207-266. https://doi.org/10.1111/j.1601-5223.1928.tb02488.x

Tumanov, D.V. (2019). Analysis of non-morphometric morphological characters used in the taxonomy of the genus Pseudechiniscus (Tardigrada: Echiniscidae). Zoological Journal of the Linnean Society. https://doi.org/10.1093/zoolinnean/zlz097

Urbanowicz, C. (1925). Sur la variabilité de Macrobiotus oberhaeuseri. Bulletin Biologique de la France et de la Belgique 59, 124-142.

van der Land, J. (1966). The Tardigrada of the Scottish Lake Survey described as new species by James Murray. Proceedings of the Royal Society of Edinburgh, Section B, Biological Sciences 69(3-4), 298-320. https://doi.org/10.1017/S0080455X0000120X

Wright, J.C. (1991). The significance of four xeric parameters in the ecology of terrestrial Tardigrada. Journal of Zoology 224, 59-77. https://doi.org/10.1111/j.1469-7998.1991.tb04788.x

Zawierucha, K., Dziamięcki, J., Jakubowska, N., Michalczyk, Ł. \& Kaczmarek, Ł. (2014). New tardigrade records for the Baltic states with a description of Minibiotus formosus sp. $\mathrm{n}$. (Eutardigrada, Macrobiotidae). Zookeys 408, 81105.

https://doi.org/10.3897/zookeys.408.6612 